\title{
Lushai Language
}

National Cancer Institute

\section{Source}

National Cancer Institute. Lushai Language. NCI Thesaurus. Code C154013.

A Sino-T ibetan language spoken by the Mizo people in the Mizoram state of India and Chin State in Burma. 